\title{
PRODUKSI ENZIM SELULASE KASAR DARI BAKTERI SELULOLITIK
}

\author{
Monalisa Nababan, Ida Bagus Wayan Gunam*, I Made Mahaputra Wijaya \\ PS Teknologi Industri Pertanian, Fakultas Teknologi Pertanian, Universitas Udayana, Kampus Bukit \\ Jimbaran, Badung, Kode pos : 80361; Telp/Fax : (0361) 701801.
}

Diterima 30 Nopember 2018 / Disetujui 11 Februari 2019

\begin{abstract}
The purpose of this research was to elucidate the potentials of cellulolytic bacteria isolates in producing crude cellulose enzymes and to determine the ability of exoglucanase enzymes and endoglucanase enzymes produced from selected cellulolytic bacteria isolates. Ten potential isolates from previous research were confirmed using 1\% Carboxymethyl Cellulose (CMC) media with the addition of Congo red and four potential isolates were obtained which then crude cellulose production and enzyme activity tests were carried out using cellulose substrates such as Carboxymethyl Cellulose (CMC), and Filter Paper (FP) Whattman number 1. The exoglucanase enzyme activity was obtained between $0.069 \mathrm{IU} / \mathrm{mL}$ to $0.072 \mathrm{IU} / \mathrm{mL}$. The activity test of endoglucanase enzyme was obtained between $0.069 \mathrm{IU} / \mathrm{mL}$ to 0.074 $I U / m L$. Cellulose degradation was obtained between $3.32 \%$ to $11.37 \%$. Isolate that have the highest enzymatic activity and cellulose degradation ability was B2S8.
\end{abstract}

Keywords: Cellulolytic bacteria, Cellulase enzyme, Enzyme activity, Congo red.

*Korespondensi Penulis:

Email : ibwgunam@unud.ac.id 


\section{PENDAHULUAN}

Enzim merupakan protein yang berfungsi sebagai katalis untuk proses biokimia. Suatu enzim dapat mempercepat reaksi $10^{8}$ sampai $10^{11}$ kali lebih cepat dibandingkan ketika reaksi tersebut tidak menggunakan katalis (Hasibuan et al., 2006). Enzim selulase dapat diaplikasikan untuk memperhalus bubur kertas pada industri kertas, menjaga warna kain agar tetap cemerlang pada industri tekstil, meningkatkan kualitas pada industri pangan, sebagai dekomposer bahan-bahan organik, meningkatkan nutrisi pakan ternak, berperan penting dalam biokonversi selulosa menjadi berbagai komoditas senyawa kimia dan dapat mengurangi dampak negatif dari polusi limbah terhadap lingkungan (Kirk, 2002). Enzim selulase dimanfaatkan juga dalam proses fermentasi dari biomassa menjadi biofuel seperti bioetanol dan juga digunakan sebagai pengganti bahan kimia pada proses pembuatan alkohol dari bahan yang mengandung selulosa (Fan et al., 2006). Keberadaan enzim selulase dalam suatu reaksi dapat memaksimumkan konversi selulosa menjadi gula sederhana dan etanol yang dihasilkan lebih tinggi (Dayatmo et al, 2006).

Enzim selulase atau enzim yang dikenal dengan nama sistematik $\beta-1.4$ glukan-4-glukano hidrolase adalah enzim yang dapat menghidrolisis selulosa dengan memutus ikatan glikosidik $\beta-1.4$ dalam selulosa, selodektrin, selobiosa, dan turunan selulosa lainnya menjadi gula sederhana atau glukosa (Aryani, 2012). Sistem pemecahan selulosa menjadi glukosa terdiri atas tiga jenis enzim selulase yaitu endo- $\beta-1.4-$ glukanase, ekso- $\beta$-1.4-glukanase, dan $\beta$-glukosidase (Aryani, 2012). Ekso- $\beta-1.4-D-$ glukanase yang mengurai selulosa dari ujung pereduksi dan non-pereduksi untuk menghasilkan selulosa dan atau glukosa, dan $\beta$-glukosidase (selobiase) yang mengurai selobiosa untuk menghasilkan glukosa (Meryandini et al., 2010). Enzim selulase pada umumnya selain dapat diperoleh dari mikroorganisme juga dapat diproduksi dari tanaman dan hewan (Yusak, 2004). Enzim dari mikroorganisme lebih banyak digunakan dibandingkan dari tanaman atau hewan karena mikroorganisme dapat berkembangbiak dengan cepat, pertumbuhan relatif mudah diatur, enzim yang dihasilkan tinggi sehingga ekonomis bila digunakan untuk industri, dan enzim yang dihasilkan lebih stabil (Yusak, 2004). Mikroorganisme penghasil enzim dapat berupa fungi dan bakteri, mikroorganisme penghasil selulase dari kelompok bakteri menjadi pilihan utama karena memiliki pertumbuhan yang cepat sehingga waktu yang dibutuhkan untuk memproduksi selulase lebih pendek (Alam et al., 2004).

Produksi enzim selulase menggunakan media Carboxymethyl Cellulose (CMC) karena dalam media ini mengandung selulosa yang digunakan sebagai substrat pada reaksi enzimatis (Meryandini et al., 2010). Sumber karbon yang berfungsi sebagai sumber energi sel dan unsur utama dalam pembentukan sel dipenuhi oleh adanya CMC (Nuryana, 2016). Carboxymethyl Cellulose (CMC) merupakan substrat terbaik untuk menginduksi sintesis enzim selolitik ekstraseluler dan konsentrasi CMC 1\% merupakan konsentrasi yang optimum untuk produksi selulase (Alam et al., 2004).

Bakteri selulolitik merupakan bakteri yang dapat menghidrolisis kompleks selulosa menjadi oligosakarida yang lebih kecil dan akhirnya menjadi glukosa (Nurrochman, 2015). Glukosa tersebut digunakan sebagai sumber nutrisi dan karbon bagi pertumbuhan organisme ini (Tri Retno et al., 2011). Bakteri selulolitik mensintesis seperangkat enzim yang dapat menghidrolisis selulosa. Mikroba mensintesis enzim selulase selama tumbuh pada media selulase (Yogyaswari et al., 2016). Enzim selulase kasar pada isolat bakteri selulolitik termasuk 
enzim ekstraseluler, sehingga dapat diekstrak dengan cara disentrifugasi (Saropah, 2013). Fungsi utama enzim ekstraseluler adalah mengubah nutrien di sekitar agar masuk ke dalam sel sebagai energi untuk pertumbuhan sel (Aulanni'am, 2005). Bakteri selulolitik menarik untuk dilakukan eksplorasi karena laju pertumbuhannya yang cepat, kompleksitas enzim dan variabilitas habitat yang mendukung (Nurrochman, 2015). Sehingga sangat cocok untuk dilakukan produksi dan uji aktivitas enzim selulase kasar dari bakteri selulolitik yang selanjutnya dapat digunakan sebagai bahan dalam pembuatan bioetanol (Chasanah et al., 2013).

\section{METODE PENELITIAN}

\section{Bahan dan Alat}

Bahan yang digunakan dalam penelitian ini yaitu: 10 isolat bakteri selulolitik potensial yang sudah diranking berdasarkan Indeks Selulolitik (IS) dari 2 penelitian sebelumnya, $\mathrm{K}_{2} \mathrm{HPO}_{4},\left(\mathrm{NH}_{4}\right)_{2} \mathrm{SO}_{4}$, $\mathrm{MgSO}_{4} .7 \mathrm{H}_{2} \mathrm{O}$, NaCl, Yeast extract, $\mathrm{CaCl}_{2} \cdot 2 \mathrm{H}_{2} \mathrm{O}$, agar, akuades, buffer sodium sitrat, $\mathrm{NaOH}$, Carboxymethyl Cellulose (CMC) (MERCK), kertas filter (Whatman no.1), Congo red (HIMEDIA).

Alat yang digunakan dalam penelitian ini yaitu UV-Vis Spektrofotometer (Thermo scientific), $\mathrm{pH}$ meter (Schott instrumen), autoclave (Hirayama), laminar air flow (Kojair), inkubator (Memmert), vortex (Maxi Max II), gelas ukur (Pyrex), Erlenmeyer (Pyrex), tabung reaksi (Pyrex), termometer, pipet mikro, pipet tetes, mikrotube, coolbox, magnetik stirer, hot plate, timbangan analitik, bunsen, penjepit, botol duran, cawan petri, jarum ose, kapas, aluminium foil.

\section{Pelaksanaan Penelitian Pemilihan isolat}

Isolat yang dipilih untuk uji konfirmasi ulang secara kualitatif merupakan 10 isolat yang telah diranking berdasarkan Indeks
Selulolitik (IS) dari 2 penelitian sebelumnya yakni penelitian Ella (2018) tentang isolasi dan skrining bakteri selulolitik dari beberapa tanah hutan di Bali, dan penelitian Zainul (2018) tentang isolasi bakteri selulolitik pendegradasi selulosa dari kompos.

\section{Pembuatan media}

Pembuatan media padat untuk uji konfirmasi bakteri selulolitik terdiri dari: $\mathrm{KH}_{2} \mathrm{PO}_{4} 1,36 \mathrm{~g},\left(\mathrm{NH}_{4}\right)_{2} \mathrm{SO}_{4} 1 \mathrm{~g}, \mathrm{MgSO}_{4} .7 \mathrm{H}_{2} \mathrm{O}$ $0,2 \mathrm{~g}, \mathrm{NaCl} 2 \mathrm{~g}$, yeast ekstrak $1 \mathrm{~g}$, $\mathrm{CaCl}_{2} .2 \mathrm{H} 2 \mathrm{O} 0,01 \mathrm{~g}$, CMC $5 \mathrm{~g}$, agar $15 \mathrm{~g}$ dalam satu liter akuades pada $\mathrm{pH}$ 6,8-7,2 yang selanjutnya dicampur dan dipanaskan sampai mendidih sambil diaduk hingga larut lalu dimasukkan ke dalam botol duran 1 liter. Pembuatan media cair sama dengan pembuatan media padat hanya saja tidak menggunakan agar. Kemudian disterilisasi dengan menggunakan outoclave dengan suhu $121{ }^{\circ} \mathrm{C}$ selama 15 menit. Media didinginkan sampai suhu $50{ }^{\circ} \mathrm{C}$. Media harus dalam keadaan steril (tidak ditumbuhi dengan mikroba lain yang tidak diharapkan) agar kultur mikroba yang dihasilkan tidak terkontaminasi (Gupta et al., 2012; Dar et al., 2015).

\section{Uji konfirmasi secara kualitatif}

Uji konfirmasi secara kualitatif dilakukan dengan cara menggores kembali 10 isolat yang sudah diranking dari penelitian sebelumnya pada medium agar CMC

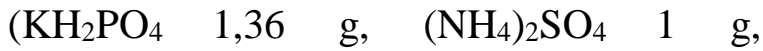
$\mathrm{MgSO}_{4} .7 \mathrm{H}_{2} \mathrm{O} 0,2 \mathrm{~g}, \mathrm{NaCl} 2 \mathrm{~g}$, yeast ekstrak 1 $\mathrm{g}, \mathrm{CaCl}_{2} .2 \mathrm{H}_{2} \mathrm{O} 0,01 \mathrm{~g}, \mathrm{CMC} 5 \mathrm{~g}$, agar $15 \mathrm{~g}$, dan akuades $1 \mathrm{~L})$. Kemudian diinkubasi pada suhu $37{ }^{\circ} \mathrm{C}$ selama 2 hari. Selanjutnya, 10 isolat ditotol pada medium CMC agar lalu diinkubasi pada suhu $37^{\circ} \mathrm{C}$ selama 2 hari dan ditambahkan cairan Congo red 0,2 g, didiamkan selama 15 menit lalu dibilas dengan $\mathrm{NaCl} 1 \mathrm{M}$ (Gupta et al., 2012).

Indikator dari uji konfirmasi bakteri selulolitik secara kualitatif yaitu dengan 
melihat adanya zona bening. Nilai Indeks Selulolitik (IS) dihitung dengan membandingkan nilai diameter zona bening dan nilai diameter koloni bakteri.

IS $=\frac{\text { Diameter Zona Bening-Diameter Koloni }}{\text { Diameter Koloni }}$

\section{Produksi enzim selulase kasar}

Tiga isolat dengan nilai indeks selulolitik tertinggi berdasarkan hasil uji konfirmasi, kemudian dilakukan peremajaan dengan menginokulasikan 1 ose isolat ke tabung reaksi yang berisi $5 \mathrm{~mL}$ medium selulolitik yang mengandung CMC $1 \%$, diinkubasi pada suhu ruang selama 42 jam dan digojog dengan kecepatan $150 \mathrm{rpm}$. Selanjutnya, dilakukan perbanyakan sel dengan menginokulasikan hasil peremajaan ke Erlenmeyer $250 \mathrm{~mL}$ yang berisi $150 \mathrm{~mL}$ medium selulolitik yang mengandung $\mathrm{CMC}$ $1 \%$, diinkubasi pada suhu ruang selama 72 jam dan digojog dengan kecepatan $150 \mathrm{rpm}$. Selanjutnya disentrifugasi dengan kecepatan 15.000 rpm pada suhu $4{ }^{\circ} \mathrm{C}$ selama 5 menit dan dicuci sebanyak 2 kali pengulangan dengan menggunakan $\mathrm{NaCl} 0.85 \%$ dan kemudian diatur $\mathrm{OD}_{660 \mathrm{~nm}}=5$ (Gupta et al., 2012).Penggunaan media CMC pada produksi enzim selulase kasar berfungsi sebagai substrat dan sebagai zat penginduksi (inducer) untuk menghasilkan enzim selulase kasar. Substrat CMC juga dimanfaatkan oleh bakteri sebagai sumber karbon untuk menghasilkan glukosa (Apriani et al., 2014).

Sel isolat selanjutnya diinokulasi sebanyak $1 \mathrm{~mL}$ pada Erlenmeyer $250 \mathrm{~mL}$ yang berisi kertas saring cair sebanyak $20 \mathrm{~mL}$ (tidak mengandung CMC). Media berisi kertas saring (Whatman no.1) kering dengan ukuran 1x6 $\mathrm{cm}^{2}$ dan dengan berat tertentu.Kemudian media diinkubasi pada suhu ruang selama 10 hari, digojog di atas shaker dengan kecepatan 100 rpm (Wen-Jing et al., 2005). Setelah diinkubasi, kertas filter dicuci dan masing-masing media disentrifugasi. Media cair yang didapat selanjutnya disentrifugasi dengan kecepatan $14.000 \mathrm{rpm}$ selama 5 menit pada suhu $4{ }^{\circ} \mathrm{C}$ (Duza \& Mastan, 2013). Enzim kasar (supernatan) yang diperoleh selanjutnya dilakukan uji aktivitas eksoglukanase dan endoglukanase.

Uji kuantitatif aktivitas enzim selulase (uji eksoglukanase dan endoglukanase)

Aktivitas eksoglukanase (FPase) diuji dengan menggunakan campuran reaksi yang mengandung $1 \mathrm{~mL}$ larutan enzim kasar (supernatan) dengan 2 buah $(1 \times 1.5 \mathrm{~cm})$ kertas Whattman No.1 dan $1 \mathrm{~mL}$ buffer sodium asetat $50 \mathrm{mM}$ (pH 5.0) diinkubasi pada suhu $50{ }^{\circ} \mathrm{C}$ selama 1 jam. Reaksi dihentikan dengan menambahkan $3 \mathrm{~mL}$ asam dinitrosalisilat lalu dididihkan selama 5 menit (Dar et al., 2015). Aktivitas endoglukanase (CMCase) diuji dengan menggunakan campuran reaksi yang mengandung $1 \mathrm{~mL}$ larutan enzim kasar (supernatan) dengan 1 $\mathrm{mL}$ larutan 1\% CMC pada buffer sodium asetat $50 \mathrm{mM}$ (pH 5.0) diinkubasi pada suhu $50{ }^{\circ} \mathrm{C}$ selama 15 menit. Reaksi dihentikan dengan menambahkan $3 \mathrm{~mL}$ asam dinitrosalisilat lalu dididihkan selama 5 menit (Dar et al., 2015).

\section{Perhitungan aktivitas enzim selulase}

Aktivitas selulase dinyatakan dalam satuan internasional yaitu Unit/milliliter (U/mL). Satu unit merupakan jumlah enzim yang dibutuhkan untuk memecah $1 \mu$ mol selulosa menjadi gula tereduksi per menit pada kondisi pengujian. Kadar gula tereduksi yang dihasilkan dari hidrolisis selulosa dengan enzim selulase berdasarkan nilai absorbansi pada $\lambda 540 \mathrm{~nm}$ (Duza and Mastan 2013; Dar et al., 2015)

\section{HASIL DAN PEMBAHASAN}

\section{Uji Kofirmasi Bakteri Selulolitik terhadap Produksi Enzim Selulase Kasar secara Kualitatif}


Uji konfirmasi bakteri selulolitik secara kualitatif merupakan proses untuk mengetahui kemampuan bakteri selulolitik dalam menghasilkan enzim selulase (Andhikawati et al., 2014). Uji konfirmasi dilakukan terhadap 10 isolat potensial yang sudah dilakukan uji skrining dan dirangking dari penelitian sebelumnya. Selanjutnya dilakukan penggoresan ulang dengan menggores bakteri kedalam media CMC agar lalu diinkubasi pada suhu $37{ }^{\circ} \mathrm{C}$ selama 48 jam (Gupta et al., 2012). Uji konfirmasi ulang dilakukan dengan cara mentotol bakteri ke dalam media CMC padat lalu diinkubasi pada suhu $37{ }^{\circ} \mathrm{C}$ selama 2 hari, ditambahkan cairan Congo red, didiamkan selama 15 menit lalu dibilas dengan $\mathrm{NaCl} 1 \mathrm{M}$ (Gupta et al., 2012). Selanjutnya zona bening dan besar koloni diukur untuk mendapatkan Indeks Selulolitik (IS).

Zhang et al., (2006) menjelaskan bahwa pewarnaan dengan menggunakan Congo red akan berdifusi ke dalam media agar dan hanya akan diabsorbasi oleh rantai panjang polisakarida yang memiliki ikatan $\beta$ D-glukan. Selanjutnya pewarna Congo red dibilas dengan menggunakan larutan $\mathrm{NaCl} 1$ $\mathrm{M}$ yang berfungsi untuk memperjelas zona bening yang terbentuk sehingga lebih mudah diamati (Astriani, 2017). Carboxymethyl Cellulose (CMC) merupakan substrat terbaik untuk produksi selulase karena dapat menginduksi bakteri untuk memproduksi enzim selulase (Idiawati et al., 2015). Menurut Ochoa-Solano dan Olmos-Soto (2006), isolat yang menghasilkan diameter zona bening dua kali diameter koloni merupakan produser enzim yang potensial. Sehingga adanya aktivitas selulolitik bakteri secara kualitatif dapat dicirikan oleh terbentuknya zona bening yang berada disekeliling koloni bakteri yang tumbuh pada media selektif CMC (Ochoa-Solano dan Olmos-Soto, 2006) dapat dilihat pada Gambar 7.

Tabel 1. Indeks Selulolitik (IS) dari 10 isolat sebelum uji konfirmasi

\begin{tabular}{lccc}
\hline No & Kode Isolat & Indeks Selulolitik & Ranking \\
\hline 1 & BT1.2 & 7,98 & 1 \\
2 & B2S8 & 7,76 & 2 \\
3 & SB3.5B & 7,30 & 3 \\
4 & G2 8 & 6,41 & 4 \\
5 & B1S3 & 6,30 & 5 \\
6 & G1 4 & 5,86 & 6 \\
7 & G2 10 & 5,55 & 7 \\
8 & B2S9 & 4,84 & 8 \\
9 & G2 2 & 4,64 & 9 \\
10 & B2S5 & 4,50 & 10 \\
\hline
\end{tabular}

Keterangan : Sepuluh isolat potensial yang menunjukkan zona bening tertinggi sebelum uji konfirmasi menggunakan media Carboxymetyl Cellulose (CMC) dengan penambahan Congo red. Kode BT (Buyan Tabanan), BS (Bondowoso Sampel), SB (Sangeh), G (Gilimanuk) dengan suhu inkubasi $37 \mathrm{oC}$ dan 55 oC selama $2 \times 24$ jam.

Nilai Indeks Selulolitik (IS) yang didapat pada penelitian ini sudah termasuk kategori sedang ke tinggi. Menurut penelitian Behera (2014), tentang isolasi dan identifikasi bakteri pengurai selulosa dari tanah mangrove delta sungai Mahanadi yang mendapatkan nilai indeks sebesar 1.18 hingga $2.5 \mathrm{~cm}$ sedangkan penelitian yang 
dilakukan oleh Lu et al., (2005) berhasil mengisolasi bakteri dari kompos limbah sayuran denga lebar zona bening terbesar yaitu $6.20 \mathrm{~cm}$ sedangkan penelitian yang dilakukan oleh Noor et al., (2015) yang mengisolasi bakteri selulolitik dari berbagai sampel, salah satunya dari sampel kotoran sapi dan jerami padi yang mendapatkan hasil zona bening tertinggi sebesar $2.93 \mathrm{~cm}$.

Tabel 2. Indeks Selulolitik (IS) dari 10 isolat setelah uji konfirmasi

\begin{tabular}{lccc}
\hline No & Kode Isolat & Indeks Selulolitik & Ranking \\
\hline 1 & G14 & 4,32 & 1 \\
2 & B2S8 & 3,98 & 2 \\
3 & G22 & 3,49 & 3 \\
4 & G210 & 3,40 & 4 \\
5 & B1S3 & 3,37 & 5 \\
6 & G28 & 3,27 & 6 \\
7 & BT1.2 & 3,11 & 7 \\
8 & SB3.5B & 2,91 & 8 \\
9 & B2S5 & 2,74 & 9 \\
10 & B2S9 & 1,43 & 10 \\
\hline
\end{tabular}

Keterangan : Sepuluh isolat potensial yang menunjukkan zona bening tertinggi setelah uji konfirmasi menggunakan media Carboxymethyl Cellulose (CMC) dengan penambahan Congo red. Kode BT (Buyan Tabanan), BS (Bondowoso Sampel), SB (Sangeh Badung), G (Gilimanuk) dengan suhu inkubasi $37^{\circ} \mathrm{C}$ selama $2 \times 24$ jam.

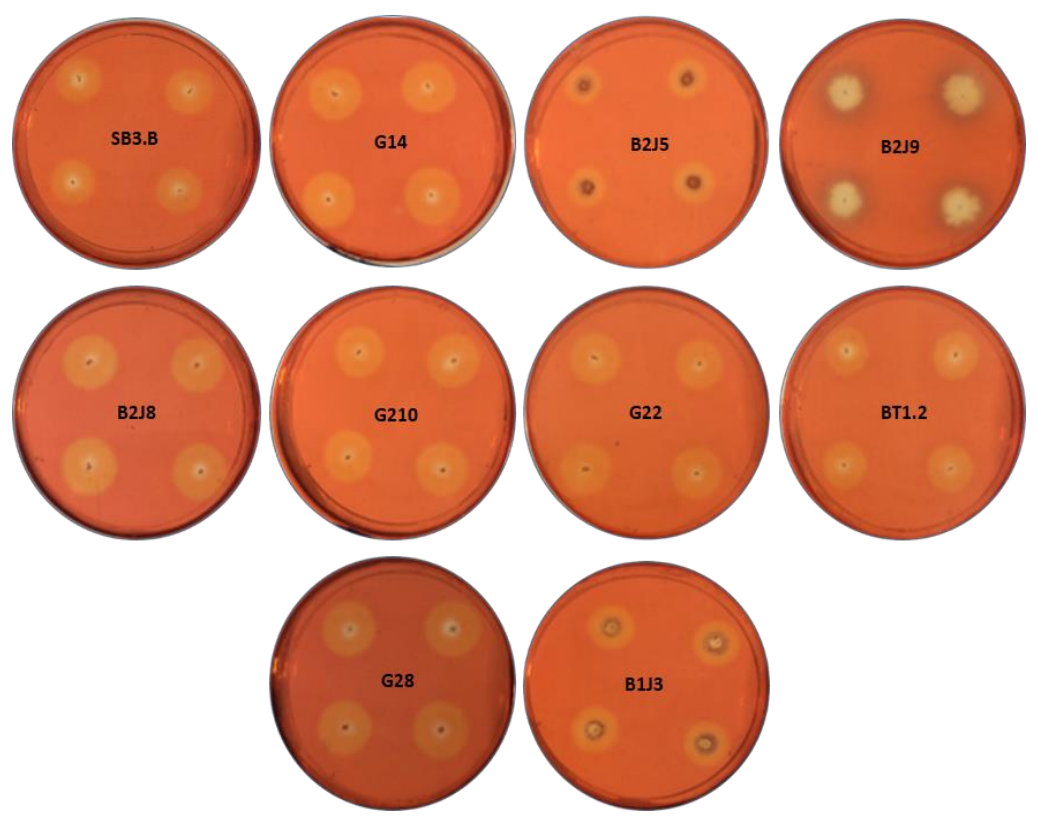

Gambar 7. Uji konfirmasi bakteri selulolitik pada media CMC menggunakan metode Congo red setelah inkubasi $2 \times 24$ jam.

\section{Produksi Enzim Selulase Kasar}

Produksi enzim selulase kasar dilakukan dengan sentrifugasi dengan memisahkan suspensi bakteri (pellet) dengan bagian supernatan sebagai enzim kasar. Menurut Aulanni'am (2005), enzim selulase 
dari bakteri selulolitik termasuk ke dalam golongan enzim ekstraseluler sehingga dapat diekstrak dengan disentrifugasi. Proses sentrifugasi dilakukan pada suhu dingin yaitu pada suhu $4{ }^{\circ} \mathrm{C}$ selama 5 menit pada kecepatan 15.000 rpm (Gupta et al., 2012). Sentrifugasi pada suhu dingin bertujuan untuk mencegah terjadinya denaturasi protein pada enzim akibat suhu tinggi (Aulanni' am, 2005).

Media CMC digunakan pada produksi enzim selulase kasar berfungsi sebagai substrat dan sebagai zat penginduksi (inducer) untuk menghasilkan enzim selulase kasar (Pertiwi, 2017). Substrat CMC juga dimanfaatkan oleh bakteri sebagai sumber karbon untuk menghasilkan glukosa (Apriani et al., 2014). Apabila semakin banyak karbon dalam media produksi maka enzim selulase yang dihasilkan juga semakin meningkat (Saropah et al., 2012). Sehingga, untuk produksi enzim pada penelitian ini menggunakan konsentrasi substrat CMC 1\% berdasarkan penelitian yang telah dilakukan sebelumnya (Alam et al., 2004).

\section{Uji Aktivitas Enzim Selulase}

Tabel 3. Data Uji Aktivitas Enzim Selulase 3 Isolat Potensial

\begin{tabular}{lcccr}
\hline Kode Isolat & CMCase & FPase & Degradasi FP $(\%)$ & SD \\
\hline B2S8 & $0,069 \mathrm{IU} / \mathrm{mL}$ & $0,071 \mathrm{IU} / \mathrm{mL}$ & $11,37 \%$ & 1,706 \\
G14 & $0,071 \mathrm{IU} / \mathrm{mL}$ & $0,072 \mathrm{IU} / \mathrm{mL}$ & $6,27 \%$ & 1,325 \\
G22 & $0,074 \mathrm{IU} / \mathrm{mL}$ & $0,069 \mathrm{IU} / \mathrm{mL}$ & $3,32 \%$ & 0,934
\end{tabular}

Keterangan : Dari 10 isolat dipilih 3 isolat yang menunjukkan aktivitas enzim tertinggi. Kode BS (Bondowoso Sampel), G (Gilimanuk). Endoglukanase (CMCase) dan Eksoglukanase (FPase).

Pada Tabel 3 dapat dilihat hasil dari 3 isolat potensial yang sudah dilakukan produksi enzim selulase kasar serta pengujian aktivitas enzim endoglukanase dan eksoglukanase. Dari pengujian aktivitas enzim endoglukanase didapat aktivitas antara $0,069 \mathrm{IU} / \mathrm{mL}$ sampai $0,074 \mathrm{IU} / \mathrm{mL}$. Sementara uji aktivitas enzim eksoglukanase didapat aktivitas antara $0,069 \mathrm{IU} / \mathrm{mL}$ sampai 0,072 IU/mL. Dapat juga dilihat persentase degradasi selulosa yang didapat antara 3,32\% sampai $11,37 \%$. Data hasil aktivitas enzim yang didapat pada penelitian ini sudah termasuk kategori sedang ke tinggi jika dibandingkan dengan penelitian-penelitian sebelumnya. Menurut penelitian Gupta et al. (2012), tentang isolasi dan identifikasi bakteri selulolitik pendegradasi selulosa untuk uji aktivitas enzim eksoglukanase didapat aktivitas antara $0.012 \mathrm{IU} / \mathrm{mL}$ sampai $0.196 \mathrm{IU} / \mathrm{mL}$ dan uji aktivitas enzim endoglukanase didapat aktivitas antara 0.162 IU/mL sampai $0.400 \mathrm{IU} / \mathrm{mL}$, persentase degradasi selulosa yang didapat antara $55 \%$ sampai $65.7 \%$.

Menurut penelitian Pertiwi (2017) tentang karakterisasi enzim selulase yang dihasilkan dari khamir Candida utilis untuk uji aktivitas enzim eksoglukanase didapat aktivitas tertinggi sebesar $0.0948 \mathrm{IU} / \mathrm{mL}$ dan uji aktivitas enzim endoglukanase didapat aktivitas sebesar $0.0369 \mathrm{IU} / \mathrm{mL}$. Menurut penelitian Dar et al. (2015) tentang isolasi bakteri selulolitik dari saluran gastrointestinal Achatina fulica (Gastropoda: Pulmonata) dan evaluasi untuk biodegradasi selulosa untuk uji aktivitas enzim eksoglukanase didapat aktivitas sebesar $3116.92 \mathrm{IU} / \mathrm{mL}$ dan uji aktivitas enzim endogukanase didapat aktivitas sebesar $501.75 \mathrm{IU} / \mathrm{mL}$. Sedangkan penelitian Shaikh et al. (2013) tentang isolasi dan skrining bakteri selulolitik dari beberapa lingkungan yang berbeda (limbah industri kertas, sampah kota, perkebunan tebu, taman dan daerah pembuatan perabot kayu) dengan konsentrasi 
substrat CMC 1\% didapat aktivitas enzim selulase sebesar $3.0 \mathrm{IU} / \mathrm{mL}$ sampai 5.2 $\mathrm{IU} / \mathrm{mL}$.

\section{KESIMPULAN DAN SARAN}

\section{Kesimpulan}

Berdasarkan penelitian yang didapatkan maka dapat disimpulkan bahwa isolat-isolat bakteri selulolitik memiliki potensi dalam memproduksi enzim selulase kasar dan mempunyai kemampuan aktivitas enzim yang berbeda. Isolat yang memiliki aktivitas selulase tertinggi adalah isolat B2S8 dengan aktivitas enzim eksoglukanase sebesar 0,071 IU/mL, aktivitas enzim endoglukanase sebesar $0,069 \mathrm{IU} / \mathrm{mL}$ dan degradasi selulosa sebesar $11,37 \%$.

\section{Saran}

Berdasarkan hasil penelitian, maka dapat disarankan bahwa perlu dilakukan uji lanjutan mengenai $\mathrm{pH}$ dan suhu optimum dalam produksi dan uji aktivitas enzim selulase kasar dari bakteri selulolitik.

\section{DAFTAR PUSTAKA}

Alam, M.Z., Manchulur, M.A., and Anwar, M.N. 2004. Isolation Purification, Characterization of Cellulolytic Enzym Producer by the Isolate Streptomyces omiyaensis. Perkist Journal Biology Scientific, 7 (10):1647-1653.

Andhikawati, A., Oktavia, Y., Ibrahim, B., \& Tarman, K. (2014). Isolation and Screening of Endophytic Marine Fungi for Cellulase Production. Jurnal Ilmu dan Teknologi Kelautan Tropis, 6(1).

Apriani, K., Haryani, Y., Kartika, G. 2014. Produksi dan Uji Aktivitas Selulase dari Isolat Bakteri Selulolitik Sungai Indragari. JOM FMIPA, 1(2):261- 267.

Aryani, S. W. (2012). Isolasi dan karakterisasi Ekstrak Kasar Enzim Selulase dari Kapang Selulolitik Mucor sp. B2. Doctoral dissertation. Universitas Airlangga: Banyuwangi.

Astriani, M. 2017. Skrining Bakteri Selulolitik Asal Tanah Kebun Pisang (Musa paradisiaca). Jurnal Biota, 3(1):6-10.

Aulanni'am. 2005. Protein dan Analisisnya. Citra Mentari Grup: Malang.

Behera, B.C., Parida, S., Dutta, S.K., and Thatoi, H.N. 2014. Isolation and identification of cellulose degrading bacteria from mangrove soil Mahanadi river delta and their cellulose production ability. American Journal of Microbiologcal Research, (2):4146.

Chasanah, E., Dini, I. R., and Mubarik, N. R. 2013. Karakterisasi Enzim Selulase PMP 0126Y dari Limbah Pengolahan Agar. Jurnal Pascapanen dan Bioteknologi Kelautan dan Perikanan, 8(2):103-113.

Dar, A.M., Pawar, K.D., Jadhav, J.P., and Pandit, R.S., 2015. Isolation of cellulytic bacteria from the gastrointestinal tract of Achatina fulica (gastroda : pulmonata) and their evaluation form cellulose biodegration. International biodeterioration and biodegradation, 98:73-80.

Dayatmo, D., \& Santoso, H. H. (2015). Pembuatan Bioethanol Dari Limbah Ampas Pati Aren Dengan Metode Hidrolisis Enzimatis Menggunakan Enzim Ligninolitik Dari Jamur Pelapuk Putih. Jurnal Konversi, 4(2):43-52.

Duza, M.B., Mastan, S.A. 2013. Isolation, characterization and screening of enzyme producing bacteria from different soil samples. International Journal of pharma and bio sciences, 4 
(2):813-824.

Fan, Z., South, C., Lyford, K., Munsie, J., van Walsum, P., and Lynd, L. R. 2003. Convertion of Paper Sludge to Ethanol, II: Proces Design and Economic Analysis. Bioprocess and Biosystems Engineering, 26(2):93-101.

Gupta, P., Samant, K., and Sahu, A. 2012. Isolation of cellulose-degrading bacteria and determination of their cellulolytic potential. International Journal of Microbiology, 10:1-5.

Hasibuan, M. A., Restuhadi, F., dan Rossi, E. 2017. Uji Aktivitas Enzim Selulolitik Dari Bekicot (Achatina Fulica) pada Beberapa Substrat Limbah Pertanian. Jurnal Online Mahasiswa (JOM) Bidang Pertanian, 4(1):1-12.

Idiawati, N., Harfinda, E. M., dan Arianie, L. (2015). Produksi Enzim Selulase oleh Aspergillus Niger pada Ampas Sagu. Jurnal Natur Indonesia, 16(1):19.

Meryandini A., Widosari W., Maranatha B., Sunarti TC., Rachmania N., and Satria H. 2010. Isolasi bakteri selulolitik dan karakterisasi enzimnya. Jurnal Sains, 13(1):33-38.

Nurrochman, F. 2015. Eksplorasi Bakteri Selulolitik Dari Tanah Hutan Mangrove Baros Yogyakarta . Doctoral dissertation. Universitas Muhammadiyah Surakarta: Surakarta

Ocha-Solano, J.L,J. Olmos-Soto.2006. The Functional Property of Bacillus for Shrimp Feeds. Journal Food Microbiology. 23: 519-525.

Pertiwi P., Nada. 2017. Karakterisasi Enzim Selulase Yang dihasilkan Khamir Candida Utilis. Universitas Islam Negeri Alauddin: Makassar.

Saropah, D. A., Jannah, A., dan Maunatin, A.
2013. Kinetika reaksi enzimatis ekstrak kasar enzim selulase bakteri selulolitik hasil isolasi dari bekatul. Alchemy.

Shaikh, N.M., A.A. Patel., S.A. Mehta., and N.D. Petel. 2013. Isolation and Screening of Cellulolytic Bacteria Inhabiting Different Environment and Optimization of Cellulase Production. Universal Journal of Environmental Research and Technology. 3(1):39-49.

Shajahan S., Moorthy, I.G., Sivakumar, N., dan Selvakumar, G. 2017. Statistical modeling and optimization of cellulose production by Bacillus licheniformis NCIM 5556 isolated from the hot spring, Maharashtra, India. Journal of King Saud University. 29: 302-310.

Tri Retno, D., \& Nuri, W. 2011. Pembuatan bioetanol dari kulit pisang. Prosiding Seminar Nasional Teknik Kimia "Kejuangan".

Wen-Jing, L., W. Hong-Tao., Y. Shin-Jian., W. Zhi-Chao., and N. Yong-Feng. 2005. Isolation and characterizarion of mesophilic cellulose-degrading bacteria from flower stalks-vegetable waste co-composting system. Department of Environmental Science and Engineering, Thinghua University, Beijing, 100084, P.R. China. Journal of General and Applied Microbiology, 51(6):353-360.

Yusak, Y. 2004. Pengaruh Suhu dan Buffer Asetat Terhadap Hidrolisis CMC oleh Enzim Selulase dari Ekstrak Aspergillus niger dalam Media Campuran Onggok dan Dedak. Jurnal Sains Kimia. 8 (2):35-36.

Yogyaswari, S. A., Rukmi, M. I., dan Raharjo, B. 2016. Ekplorasi Bakteri Selulolitik dari Cairan Rumen Sapi Peranakan Fries Holland (Pfh) dan Limousine Peranakan Ongole (Limpo). Jurnal Biologi, 5(4):70-80. 
Zhang, Y., Himmel, M., and Mielenz, J. 2006. Outlook for cellulase improvement: screening and selecton strategis. Biotechnology advances, 24(5): 452-481. 